JOBNAME: No Job Name PAGE: 1 SESS: 10 OUTPUT: Thu Jun 26 17:10:49 2014 SUM: 86445C5F /Xpp84/wiley_journal R-S/SJP/sip v52 i3/03sip 12079

\begin{tabular}{|l|l|}
\hline \multicolumn{2}{|c|}{ Toppan Best-set Premedia Limited } \\
\hline Journal Code: SJP & Proofreader: Mony \\
\hline Article No: SJP12079 & Delivery date: 26 Jun 2014 \\
\hline Page Extent: 21 & \\
\hline
\end{tabular}

The Southern Fournal of Philosophy

Volume 52, Issue 3

September 2014

\title{
A DIRECT KANTIAN DUTY TO ANIMALS
}

\author{
Michael Gholbi
}

\begin{abstract}
Kant's view that we have only indirect duties to animals fails to capture the intuitive notion that wronging animals transgresses duties we owe to those animals. Here I argue that a suitably modified Kantianism can allow for direct duties to animals and, in particular, an imperfect duty to promote animal welfare without unduly compromising its core theoretical commitments, especially its commitments concerning the source and nature of our duties toward rational beings. The basis for such duties is that animal welfare, on my revised Kantian view, is neither a conditioned nor unconditioned good, but a final and nonderivative good that ought to be treated as an end-in-itself. However, this duty to promote animal welfare operates according to a broadly consequentialist logic that both accords well with our considered judgments about our duties to animals and explains differences between these duties and duties owed to rational agents.
\end{abstract}

In his ethical writing on animals, ${ }^{1}$ Kant defends a number of casuistical conclusions that contemporary readers are likely to find plausible. Kant opposed the "violent and cruel treatment" of animals, including their being painfully killed, worked beyond their natural capacities, subjected to experimentation "for the sake of mere speculation, when the end could be achieved without these" (MM 6:443), ${ }^{2}$ or killed merely for sport (LE 27:460). ${ }^{3}$

Michael Cholbi is Professor of Philosophy at California State Polytechnic University, Pomona, and editor of the journal Teaching Philosophy. In addition to several papers on themes in Kantian ethics, he has also published on other topics in ethics, including suicide, punishment, and lying. He is currently developing a series of manuscripts on the ethics and rationality of grief.

\footnotetext{
${ }^{1}$ For brevity, I will use the term 'animals' to refer to nonhuman animals.

${ }^{2}$ References to Kant's works are as follows: C2 (Critique of Practical Reason); C3 (Critique of Fudgment); CBH (Conjectural Beginning of Human History); G (Groundwork for the Metaphysics of Morals); IUH (Idea for a Universal History from a Cosmopolitan Point of View) LA (Lectures on Anthropology); LE (Lectures on Ethics); MM (Metaphysics of Morals); R (Religion within the Limits of Mere Reason) and TP (On the Common Saying: That May Be Correct in Theory, But Is of $\mathcal{N}_{0}$ Use in Practice). Pagination refers to volume and page numbers in the standard German edition of Kant's works, Immanuel Kant,
} 
Yet Kant's seemingly progressive conclusions about our obligations to animals rest on a theoretical basis that many of his critics find less persuasive, even troubling. Kant denies that we have any moral obligations to animals as such, because animals lack autonomous rational wills, the possession of which is a necessary condition for being an object of obligations. Kant held that we instead have indirect duties concerning animals. That is, we have moral obligations not to mistreat animals because mistreating them exemplifies, or encourages the development of, bad moral character and is therefore at odds with our chief duty to ourselves, that of moral self-perfection. Even though Kant's position logically implies much of what we usually understand our duties to animals to consist in, his position is difficult to stomach because whatever behaviors toward animals his indirect duties disallow, it disallows them for an intuitively unsatisfying reason. For when we mistreat animals, on Kant's view, it is we who are wronged, not the animals themselves. To the extent that, say, cruelty to animals is wrong on Kant's view, its wrongness has nothing per se to do with the effects of such cruelty on animals themselves.

As many Kantians have noted, the source of Kant's opposition to direct duties to animals is his "logocentric" theory of value. 4 According to this theory, rational nature or "humanity," Kant's term for the capacity to set ends according to reason ( $\mathrm{G} 4: 429)$, is the sole unconditioned value, and all other goods derive their value from their relation to rational nature. Animals presumably lack the rational capacities Kant believed constitute humanity, such as the capacities to represent considerations as reasons and to act on principles. Since Kant appeared to believe that possessing humanity was both necessary and sufficient for having moral status, that is, for being an object of direct moral duties, animals cannot be objects of direct moral duties. Indeed, the only possible moral role for animals is as "means and tools at the disposal of [our] will for the attainment of the aims at [our] discretion" (CBH 8:114). In this respect, animals have the same moral status as nonsentient material objects.

Some Kantians have tried to reconcile Kant's logocentrism with direct duties to animals, either by claiming that animals are entitled to moral status

Gesammelte Schriften ed. Royal German Academy of Sciences (Berlin: deGruyter, 1900). All translations are by Mary Gregor, as printed in The Cambridge Edition of the Works of Immanuel Kant (Cambridge: Cambridge University Press, 1999).

${ }^{3}$ Some contemporary Kantians believe that Kant's position would also condemn modern "factory farming." See Dan Egonsson, "Kant's vegetarianism," Journal of Value Inquiry 31 (1997): 473-83; and Lara Denis, "Kant's conception of duties regarding animals: Reconstruction and reconsideration," History of Philosophy Quarterly 17 (2000): 405-23, 417.

${ }^{4}$ See, for example, Allen Wood, "Kant on duties regarding nonrational nature I," Proceedings of the Aristotelian Society supp. 72 (1998): 189-210, 189 and Jon Garthoff, "Meriting Concern and Meriting Respect," Journal of Ethics and Social Philosophy 5 (2011): 1-28, 1-2. 
because they possess part of the "infrastructure" of rational nature ${ }^{5}$ or because human rational agents value their own welfare and are hence rationally compelled to confer that same value on animal welfare. ${ }^{6}$ Since these efforts at reconciliation have been criticized by others, I will not add to that chorus. ${ }^{7}$ I will instead outline how Kant's logocentric theory of value can be amended to accommodate direct duties to animals. ${ }^{8}$ In particular, I will show how Kant overlooked a possible axiological category into which animal welfare appears to fall - nonderivative value that is neither conditioned nor unconditioned because its value is independent of its relation to rational willing. Once animal welfare is placed into this category, direct duties concerning animal welfare become intelligible. On the revised Kantian view I defend here, our duties concerning animal welfare are direct but imperfect. These duties demand that moral agents adopt animal welfare as an end but does not require the performance of every act that might promote such welfare. Moreover, animal welfare is not, on the view I propose, subject to the same moral logic as human interactions. Rather, because animal welfare lacks the dignity that Kant associates with the unconditionally valuable rational will, animal welfare is amenable to consequentialist moral reasoning that Kantians reject in the domain of human interaction. Such a duty accords well with many of the specific judgments associated with a reasonable and compassionate animal ethic. At the same time however, the theory of value necessary for Kantianism to recognize direct duty to animals does not require Kantians to jettison the core commitments on which the Kantian picture of our duties to creatures who do possess humanity rests. Kantians can thus adopt a dualistic theory of value that makes sense of direct duties to animals without impugning their belief in the distinct moral standing of rational nature.

\section{ANIMALS, AUTONOMY, AND INDIRECT DUTY}

Though Kant denied animals moral status, he did not hold the Cartesian view that animals are unconscious automata. He recognized that the animal

\footnotetext{
${ }^{5}$ Wood, "Kant on duties regarding nonrational nature I," 200.

${ }^{6}$ Christine Korsgaard, "Fellow creatures," in Tanner Lectures on Human Values, vol. 25/26, ed. G. B. Peterson (Salt Lake City: University of Utah Press, 2005) and Self-Constitution (Oxford: Oxford University Press, 2009).

7 Garthoff, "Meriting Concern and Meriting Respect," 2-8, and Emer O’Hagan, "Animals, Agency, and Obligation in Kantian Ethics," Social Theory and Practice 35 (2009): 544-54.

${ }_{8}^{8}$ Garthoff pursues a similar strategy and endorses a conclusion similar to my own: that we are to treat "consciousness, whether in your own animal or in that of another, never merely as a means but always an end in itself" ("Meriting Concern and Meriting Respect," 23). As will be clear, I arrive at my conclusion through a very different argumentative route.
} 
kingdom consists of sentient creatures who are susceptible to pleasure and pain, who have identifiable interests, and whose lives can go well or badly according to standards specific to them as members of biological kinds. Furthermore, even if animals lack reason and so do not pursue their interests rationally, they nevertheless consciously respond to environmental cues in order to pursue said interests (C3 5:457). ${ }^{9}$ Yet because animals lack the autonomous rational wills that give human beings their moral standing, the only duties we could have with regard to animals are indirect duties. Indeed, Kant accuses anyone of thinking that we have direct duties to animals of being inherently confused.

As far as reason alone can judge, a human being has duties only to human beings (himself and others), since his duty to any subject is moral constraint by that subject's will. Hence the constraining (binding) subject must, first, be a person; . . A human being can therefore have no duty to any beings other than human beings; and if he represents to himself that he has such duties ... [h] e is led to this misunderstanding by mistaking his duty with regard to other beings for a duty to those beings. (MM 6:422)

Lacking rational wills, Kant claims, animals are "things," not persons, and the paradigm moral attitude of respect is properly directed only toward persons, and not things (C2 5:76, LA 7:127). Only rational beings can therefore be ends in themselves. So like other nonliving things, animals have only "relative value" (G 4:428) such that we may deal with and dispose of them at our "discretion" (LA 7:127). In this respect, animals are not categorically different from other natural or manufactured objects. On Kant's view, animals and other empirical objects are not ends-in-themselves. Hence, we neither can treat them as such nor can we fail to treat them as such. But animals can be (and, indeed, ought to be) treated as means either to our rationally chosen ends or to the chief moral end of self-perfection.

Yet Kant would be in no position to hold that we have even indirect duties concerning animals if there were not some feature of animals that distinguishes them from the stones, scraps of paper, and lawn clippings to which we have no duties at all. The feature that morally distinguishes animals from other empirical objects, according to Kant, is that they share in our capacity for suffering. To inflict, or to tolerate the infliction of, gratuitous suffering on animals "weakens or uproots" a crucial moral feeling, namely, the disposition to "love something ... even apart from any intention to use it" (MM 6:443). Since the intention to use another human being wrongs her by treating her as a mere means, any emotional disposition that encourages us to love others

${ }^{9}$ O’Hagan, "Animals, Agency, and Obligation in Kantian Ethics," 548-9. Kant believed that though animals lack "personality," they are endowed with nonrational powers of sensation and choice that elevate them above "mere machines." 
apart from their utility in satisfying our inclinations thereby discourages such mistreatment and thus assists us in fulfilling our duty to perfect our own moral nature (G 4:430-1, MM 6:387). Hence, Kant concludes we have an indirect duty to "sympathize actively" in the sufferings of other creatures and to "cultivate the compassionate natural (aesthetic) feelings in us" (MM 6:457). Our indirect duties concerning animals thus rest on the fundamental perfect duty to oneself - that of moral self-perfection. ${ }^{10}$

Regardless of the extent of these indirect duties, by grounding duties to animals in duties to self, these orthodox Kantian views do not mandate the "direct moral concern for animal welfare" ${ }^{11}$ found in ordinary moral thought. For were it not for facts about how mistreating animals expresses or encourages bad moral character, ${ }^{12}$ we would have no duties with respect to animals at all. Animals themselves are therefore largely incidental to the duties we have with regard to them, on Kant's view. So even if we follow Kant in thinking that all moral duties are at least partially duties to self, ${ }^{13}$ these views still get the role of animal welfare in our moral duties exactly wrong. Disregarding animal welfare is not wrong because it represents, or contributes to, the misuse of our moral agency. Disregarding animal welfare misuses our moral agency because it wrongs animals. This is a truth that no appeal to indirect duties can explain.

\section{UNGONDITIONED AND GONDITIONED GOODS}

Central to Kant's axiology is the distinction between unconditioned and conditioned goods. The sole unconditioned good, Kant claims, is the good rational will. All other goods, their goodness resting on their relation to the good rational will, are conditioned goods, goods that are good only on the condition that they stand in the correct relation to the good rational will. In this section I will explain how Kant's axiology forces him to categorize animals and their welfare as conditioned goods, while also arguing that this

${ }^{10}$ That our indirect duties to animals are rooted in direct duties to self is carefully emphasized by Heike Baranzke, "Tierethik, Tiernatur und Moralanthropologie im Kontext von §17 Tugendlehre," Kant-Studien 96 (2005): 336-63 and Jens Timmermann, "When the tail wags the dog: Animal welfare and indirect duty in Kantian ethics," Kantian Review 10 (2005): 128-49, 140.

${ }_{11}$ O'Hagan, "Animals, Agency, and Obligation in Kantian Ethics," 553.

${ }^{12}$ Kant's view that sensitivity to animal suffering is a "natural predisposition that is very serviceable to morality in one's relations with other people" (MM 6:443) because mistreating animals tends to make us "hard" in our "dealings with men" (LE 27:240) has been vindicated by subsequent research showing that cruelty toward animals, especially among children and adolescents, is predictive of later violence, aggression, crime, and even psychopathy. See Frank R. Ascione, "Animal Abuse and Youth Violence," Fuvenile Fustice Bulletin (U.S. Office of Juvenile Justice and Delinquency Programs: Washington, D.C.), September 2001.

13 Timmermann, "When the tail wags the dog," 139-41. 
categorization represents a kind of category mistake. To locate animal welfare in the same axiological space as the good rational will wrongly assumes that animal welfare and other goods occupy a common axiological space which has the good rational will at its center. Kant's mistake is thus akin to asking whether Paris is north or south of the moon's Sea of Tranquility. It is neither, because Paris and the Sea of Tranquility occupy different spaces within which notions such as "north" and "south" can be intelligibly deployed. In a similar vein, animal welfare occupies a distinct axiological space altogether.

In the opening paragraphs of the Groundwork, Kant offers a catalog of items that are only conditionally good. These include "talents of mind," "qualities of temperament," and other "gifts of nature"; power, health, wealth, and other "gifts of fortune"; self-control, courage, and other moral virtues; and even happiness itself. The goodness of these items is conditional in that their goodness is logically dependent on their being accompanied by, or exercised by, the good rational will. Moreover, Kant argues, many of these items are positively evil "without the basic principles" of a good rational will to guide them or correct their influence ( $\mathrm{G}$ 4:393-4). Kant mentions animals obliquely in this connection when he remarks that "beings the existence of which rests ... on nature" or "beings without reason" have only relative worth, the worth belonging to things, not persons. Only rational nature, Kant concludes, has "absolute" or unconditioned worth, so only our humanity is an "objective end" or an end in itself (G 4:428-9). Kant thus arrives at his famous statement of the Formula of Humanity: that we are to treat humanity - the capacity to set ends according to reason - always as an end in itself and never as a mere means. Respect for humanity turns out to be the only end which is also a duty.

The axiological scheme described in these passages explains why Kant was compelled to place animals in the category of a conditioned good. Much of the remainder of this article will attempt to show how Kantians can reject elements of this scheme and thereby begin to make sense of direct duties to animals. But we should first document what Kant's axiology misses about the value of animal welfare. Kant is moved to claim that we have only indirect duties concerning animals because he supposes that if animals (or their welfare) are not unconditionally good, then they must therefore be conditionally good. Although animals or their welfare being only conditionally good is the only inference Kant could draw given his taxonomy, this seems rather to reveal the limitations of that taxonomy. I contend that Kant wrongly supposed that every good is either unconditionally good in relation to all other values or conditionally good in relation to that which is unconditionally good. I propose that though nothing can be both unconditionally and conditionally good with respect to the rational will, some goods are neither, and so fall outside Kant's distinction altogether. 
The goods Kant classifies as conditioned goods in the opening paragraphs of the Groundwork are conditionally good because their goodness depends upon the presence of the (good) rational will in order to be realized. A trait such as courage can be used in the service of moral wrongdoing and is bad under those conditions. However, that same trait is good when exercised by a good rational will. Similarly, wealth can be used in the service of moral wrongdoing and is bad under those conditions, but becomes good when exercised in service of the ends chosen by a good rational will; and so forth for the other virtues, "gifts of fortune," and even happiness itself. But animal welfare is not good in this way at all. To begin with, animal welfare is not a proper instrument of our ends in the way that wealth, virtues, or other conditional goods are. Though we may take animals' welfare into account in our practical deliberation, it is nevertheless not a means to the achievement of our ends in this way. Nor does animal welfare acquire its goodness from its relation to the quality of our rational wills in the way that our own happiness does. When an animal flourishes, the goodness of such flourishing is not augmented or realized by its relation to any rational will. Similarly, when an animal suffers, the badness of such suffering is not dependent on the rational will or any moral quality thereof. A cheetah living a life in accordance with its nature - hunting gazelles, living in social groups, defending its territory - is good for cheetahs, and this goodness does not hinge upon the quality of any rational will. No act of rational willing on the part of human rational agents, be it admirable or contemptible, determines the goodness or badness of an animal's state of welfare. In stark contrast to the other conditioned goods Kant mentioned, the goodness of animal welfare is invariant in relation to rational volition. Hence, animal welfare falls through the cracks of Kant's taxonomy, for it stands outside of Kant's distinction as neither an unconditioned good nor a conditioned good in relation to the sole unconditioned good, the rational will.

I suggested earlier that Kant seems to have made a category mistake: In his axiology, all goods stand in some relation to what is unconditionally good. In the case of the good rational will, the relation is one of identity. In the case of all other goods, the relation is one wherein their goodness depends on the presence of the good rational will. What Kant seems to have overlooked is the possibility of goods that occupy a different axiological space altogether and, because of this, are atomic rather than relational in their goodness. Animal welfare, I propose, is such a good - a good whose goodness does not derive from its relation to the good rational will at all. Animal welfare thus resists Kant's taxonomy, and it is a failure of Kant's philosophical imagination that the only fashion in which animal welfare could matter in his theory is as a conditioned good. 


\section{ANIMAL WELFARE AND HUMAN HAPPINESS}

I indicated at the outset that the possibility of direct duties to animals comes into view if animal welfare belongs to an axiological category that Kant overlooked, that is, nonderivative values that are neither conditioned nor unconditioned because their value is independent of its relation to rational willing. Having suggested how animal welfare is neither conditioned nor unconditioned, I will now indicate how we may exploit Kant's understanding of the value of human happiness, the closest analogue to animal welfare, in order to investigate the ground of such duties. There is logical space, I shall argue, for animals to be more than mere things on a Kantian view-in fact, to function as ends in themselves - despite animals being neither rationally autonomous nor having the incomparable value Kant designates as dignity.

Let us begin with Kant's earlier observation that the main affinity between animals and ourselves is our shared capacity to flourish and to suffer. Like us, animals have lives that can go well or ill. For us, our lives going well- the condition in which "everything goes according to [one's] wish or will" (C2 $5: 124)$ so that our "needs and inclinations" are fully satisfied (G 4:405) - is the state Kant calls happiness. Granted, since Kant thinks of human happiness as an object of rational volition, we should not ascribe the pursuit of "happiness" to animals on the grounds that they lack the rational capacities to identify a comprehensive set of ends to constitute their happiness. Animals thus lack a rational interest in that which preserves them or provides them pleasure or pain. But these natural ends - which we may call welfare - are ends that when realized contribute to animals' lives going well, just as our having our needs and inclinations fulfilled contributes to our lives going well.

Of course, Kant is suspicious of any "heteronomous" moral theory that makes the pursuit of happiness, either one's own or that of a community, its central practical principle. Indeed, Kant believes that because acting in the service of our inclinations is the most powerful "counterweight" to fulfilling our obligations, we have at most an indirect duty to cultivate our happiness so as to mitigate its corrupting influence on our moral wills ( $G$ 4:399, 4:405, C2 5:35, 5:93, 5:156). It is crucial, however, that we not exaggerate Kant's antagonism toward the pursuit of happiness. Only the good will is unconditionally good, that is, "of itself absolutely and in all respects good" (C2 5:111. Also G 4:393, 4:396, 4:442, C2 5:62, C2 5:110). Given this, the science of morality, the investigation of a metaphysics of morals, is not the science of how to attain happiness but the science of how to become worthy of happiness, that is, to have a good will (TP 8:278, 8:283). But as noted above, that the goodness of happiness is conditioned by the good will does not entail that happiness is not itself good. Indeed, the good will needs to be accompanied by 
happiness in order for the "sole or complete good" (G 4:396) to be realized. Kant's specification of the highest good- "the whole and complete good as the object of the faculty of desire of finite rational beings" (C2 5:110)incorporates moral virtue and happiness, which are two "specifically quite different elements of the highest good" (C2 5:112). Because virtue or good will is the supreme condition of happiness, the ideal of the highest good is realized when happiness is apportioned to virtue. Virtue thus plays the leading role in the highest good, but the role of happiness is no less essential, for it "completes" virtue. And though morality is the condition of happiness being good, happiness and morality are not in "opposition," for "pure practical reason does not require that one should renounce claims to happiness but only that as soon as duty is in question one should take no account of them" (C2 5:93, TP 8:278).

All the more, happiness not being an unconditioned good does not entail that it is not good. ${ }^{14}$ As we noted earlier, that happiness is a conditioned good is a claim about its normative relationships with other goods or states of affairs. It is not a claim about happiness' causal relationship with other goods. For instance, happiness is clearly a final good. The value of happiness, in Kant's estimation, does not consist in its being a means or instrument to any other good, including a good will. Of course, Kant thought that the pursuit of happiness is the principal obstacle to having a good will, yet it does not follow from this that happiness' value is as an instrument or means to some other good. After all, that the pursuit of $\mathrm{X}$ can be a means to moral vice does not mean that, when accompanied by a good will, X's goodness rests on its being a means to the good will. More specifically, that happiness is not good when divorced from a good will does not entail that happiness, when allied with a good will, is good for the sake of the good will. Happiness, in Kant's eyes, is a good whose goodness is conceptually, though not metaphysically, independent of a good moral will.

Second, that happiness is a conditioned good is not a claim about the source of its goodness. For happiness in general appears to be a nonderivative or nonrelational good in Kant's scheme. Happiness in general, Kant thinks, consists of a set of specific ends upon which we confer value by our preferences and choices. Kant recognizes that human beings are diverse in the things that cause them pleasure or pain and are therefore diverse with respect

${ }^{14}$ Some commentators (e.g., James Skidmore, "Duties to Animals: The Failure of Kant's Moral Theory," Journal of Value Inquiry 35 (2001):, 541-59, 554-5) have not been especially careful in distinguishing the conditioned goodness of happiness from its final and nonderivative goodness, wrongly inferring that if happiness is a conditioned good, then it can neither be finally nor nonderivatively good. As a result, these commentators wrongly infer that animal welfare, being an analogue to the conditioned good of happiness, cannot ground a direct duty. 
to the elements that constitute their happiness (C2 5:25, MM 6:215). Hence, while it could be said that the specific ends we pursue under the auspices of happiness are extrinsically good by virtue of our choosing to pursue them, we nevertheless choose these ends as constituents of the ideal of happiness or happiness in general, that is, the sum satisfaction of these more specific ends. This ideal, however, does not borrow its goodness from elsewhere.

Hence, the sui generis goodness of happiness in general supervenes on the elements that constitute happiness, rather than acquiring its goodness from some relation to an object outside itself. Happiness' value, then, is nonderivative, inasmuch as its goodness does not derive from some other value.

\section{THE PURITY OF ANIMAL WELFARE}

As Kant vividly put it, an "impartial rational spectator can take no delight in seeing the uninterrupted prosperity of a being graced with no feature of a pure and good will" (G 4:393). Since animals neither deserve nor fail to deserve their prosperity, an impartial spectator cannot delight in animal prosperity in this sense. But it hardly follows that an impartial spectator ought to thereby be indifferent to the flourishing or suffering of animals. Indeed, on Kant's view, animal welfare has a claim to being a purer or more pristine good than human happiness. As Allen Wood in particular has emphasized, Kant's mistrust of our natural inclinations extends only so far as these inclinations are shaped by society, but considered in themselves, our natural inclinations are good. ${ }^{15}$ Following Rousseau, Kant maintains that the pursuit of "passions" whose objects are essentially social becomes evil only when, impelled by those same inclinations to seek community with other human agents, we become competitive with other community members. As Kant writes:

It is not the instigation of nature that arouses what should properly be called the passions, which wreak such great devastation in his originally good [animal] predisposition. His needs are but limited and his state of mind in providing for them is moderate and tranquil. ... Envy, addiction to power, avarice, and the malignant inclinations associated with these, assail his nature, which on its own is undemanding, as soon as he is among human beings. ( $\mathrm{R}$ 6:93-94)

Kant thus traces our moral corruption to what he calls in the Fourth Proposition of his "Idea for a Universal History" our "unsocial sociability" - our "propensity to enter into society, bound together with a mutual opposition

\footnotetext{
${ }^{15}$ Wood, Kantian Ethics (Cambridge: Cambridge University Press, 2008), 4.
} 
which constantly threatens to break up the society" (IUH 8:20). Ironically, then, the very pursuit of our rational ends transforms our presocial and "purely mechanical self-love" — our purely animal welfare, if you will —into a source of vice (R 6:26-7, 6:57).

Happiness, then, is conditionally good because of its capacity to corrupt our wills. However, it is striking to note that in the secularized version of Adam's fall Kant outlines in his Conjectural Beginning of Human History, Kant holds that only when reason distorts our true needs does the pursuit of the inclinations that constitute our happiness become corrupt. Happiness, divorced from our rational capacities and considered just as purely animal, is not only not corrupt, but incorruptible. Paradoxically, practical reason both introduces incentives that corrupt the inclinations rooted in our animal impulses and provides incentives in the form of moral feeling, respect for the moral law, and the like, which make it possible to act from a sense of moral duty and thereby to counteract these corrupted inclinations. Our practically rational natures are therefore both the source of, and the solution to, moral wrongdoing. Reason thus sets the basic problematic of our shared moral and social life, because it corrupts and subsequently corrects the influence of our animal inclinations. In contrast, conceived solely as products of our animal natures, our inclinations are unspoiled precisely because they are detached from rational wills, which because they are imperfect and finite are thus subject to other incentives besides the demands of the moral law. Animal welfare, because its goodness is not conditioned on the presence of the rational will, is only human happiness with this very susceptibility to moral corruption excised. Animal welfare is not only uncorrupted. It is by its nature incorruptible. And so its goodness, like that of human happiness, is nonderivative and final, but unlike human happiness it is neither unconditionally nor conditionally good.

Animal welfare is therefore an end-in-itself. Kant sometimes claims that only beings with dignity, that is, practically rational beings whose acts can exhibit moral worth, are to be understood as ends in themselves (G 4:435, MM 6:435). But what is it to be an end-in-itself? It is, first, to be an object of rational choice, or, to be an end. But where Kant further infers that only ends grounded in the unconditioned good of the rational will can be ends in themselves, that inference is incorrect. Animal welfare, I have argued, is a final and nonderivative good, worthy of choice for its own sake and due to its inherent nature. Its human analogue, happiness, is not an end in itself because of its conditional relationship to the unconditioned good. But animal welfare bears no such relationship to our rational wills. Hence, its goodness can ground a direct duty thanks to its normative independence from the rational will. By rejecting the claim that only that which is unconditionally 
good is an end in itself, it becomes apparent that animal welfare is an end in itself because it is a final and nonderivative good whose goodness is nevertheless not conditioned upon any association with rational volition. A recognizably Kantian ethics thus has logical space for ends in themselves that are more than mere things to be used (or abused) as we wish, but not yet dignified rational wills. Such ends in themselves would be worthy of choice for their own sake and not because of their relation to our contingent concerns or attitudes. Animal welfare, as both a final and non-derivative good, is such an end.

\section{FROM NONDERIVATIVE VALUE TO A DIRECT DUTY}

All this aside, one crucial task remains. Suppose that I am correct that animal welfare is a final and nonderivative good and an end-in-itself that is neither conditionally nor unconditionally good relative to the good rational will. How do these axiological claims generate a duty to promote animal welfare? The notion that the value of animal welfare could be a source of moral duties is not likely to offend consequentialists. But Kantians skeptical of my conclusions about animal welfare will argue that value is normatively downstream from reason - that something is good because it is approved of by reason, rather than the other way around. As Kant remarks, "what we are to call good must be an object of the faculty of desire in the judgment of every reasonable human being ... hence for this appraisal, reason is needed, in addition to sense" (C2 5:61). In the Kantian mind, if there is a duty to promote animal welfare, this must be an end that is also a duty. Some rational agents, due to their natural sympathy toward animals, will have animal welfare among their chosen ends, and for such agents the promotion of animal welfare would have rational force because it is an object of pleasure or sensible approval. But this could only ground a hypothetical imperative. A duty to promote animal welfare would, in contrast, have to rest on a categorical imperative, just as our duty of beneficence toward other rational agents does. How, then, can animal welfare be a necessary end of rational wills? For on the picture I have offered, animal welfare does not derive its goodness from any attitude taken toward it by rational agents. But that, some Kantians argue, is to reject a necessary condition on value and a necessary condition on moral obligation.

To a large extent, this worry echoes a now familiar debate among Kantian ethicists about whether Kantianism is best construed as a realist theory or a constructivist theory. While Kantian realists may have some reservations about adding animal welfare to a roster of values that includes rational agency, it is constructivists who are likely to have the greatest reservations about my proposal. For on their view, value must be conferred by rational 
agents. ${ }^{16}$ But (they might argue) while some rational agents may opt to confer value on animal welfare, there is nothing incoherent about them not doing so, and hence no basis for claiming that those agents must have animal welfare as one of their ends.

Whether a realist or constructivist reading of Kant's ethical writings is more plausible is a matter I leave to others. ${ }^{17}$ Constructivists such as Christine Korsgaard ${ }^{18}$ argue that any end or good independent of practical reason will necessarily fail to rationally bind us, as it can only generate hypothetical imperatives whose force depends on our inclinations. And so if moral demands are necessarily binding on rational agents, they must in turn rest on a categorical principle. Any form of realism will thus inevitably lead to moral skepticism, so classifying animal welfare in the "realist" way as I have simply cannot explain how there could be duties to promote it.

But it is not clear, even if constructivism is the only bulwark against moral skepticism, that my thesis is incompatible with Kantian constructivism. In particular, it does not seem incoherent to suppose that avoiding skepticism requires Kantians to posit that some values are conferred by rational agents, but there might nevertheless be values of a realist kind that are not conferred by rational agents. That is, all that seems necessary to avoid the skepticism that realism putatively generates is that some values be validated by practical reason. This allows for some values to be logically independent of rational volition or, in the terms I put it earlier, for there to be values that occupy a distinct axiological space from that occupied by the rational will and the objects it confers value upon by making them into ends. I am therefore not presupposing a form of Kantianism that is realist to its core. Constructivists such as Korsgaard emphasize that valuing humanity is a condition of valuing anything whatsoever. But this condition can be construed as a constraint on valuing instead of a constraint on what has value. Certainly there could not be moral obligation without moral

\footnotetext{
${ }^{16}$ Christine Korsgaard, "Kant's Formula of Humanity", in Creating the Kingdom of Ends (Cambridge: Cambridge University Press, 1996), 106-32.

${ }^{17}$ For discussions of this interpretive controversy, see Larry Krasnoff, "How Kantian is constructivism," Kant Studien 90 (1999): 385-409 and Robert Audi, The Good in the Right: A Theory of Intuition and Intrinsic Value (Princeton: Princeton University Press, 2004). Among those favoring the realist interpretation are Karl Ameriks, "On Two Non-Realist Interpretations of Kant's Ethics," in Interpreting Kant's Critiques (Oxford: Oxford University Press, 2003), 263-82; Rae Langton, "Objective and Unconditioned Value," Philosophical Review 116 (2007): 157-85; and Pauline Kleingeld, "Moral Consciousness and the 'Fact of Reason'," in Kant's Critique of Practical Reason. A Critical Guide, ed. A. Reath (Cambridge: Cambridge University Press, 2010), 55-72.

${ }^{18}$ See her Sources of Normativity (Cambridge: Cambridge University Press, 1996) and The Constitution of Agency (Oxford: Oxford University Press, 2008).
} 
agents, and on a Kantian view those agents must be morally obligated to treat their own rational agency as an end in itself. But valuing their own rational agency does not determine what else they can or ought to value nonderivatively or for its own sake. That $\mathrm{X}$ must be valued in order for $\mathrm{Y}$ to be valued (for any value of $\mathrm{Y}$ ) does not imply that Y's value must rest on its relation to $\mathrm{X}$ in the way that Kantian constructivists insist that all values must be conferred by a rational will. Kantians such as David Velleman argue that values can metaphysically depend on the existence of valuers without its being the case that all such values are valuable just insofar as they are good for those valuers. ${ }^{19}$ Likewise, animal welfare may depend on the existence of rational valuers to be valuable, but this does not entail that animal welfare can only be good for those rational valuers.

So in one respect, my view is less metaphysically austere than the constructivists'. Animal welfare exemplifies the "substantive moral realism" that constructivists such as Korsgaard reject, "normative phenomena" in the world around us whose normativity we discover rather than generate through a procedure of practical deliberation. ${ }^{20}$ Yet the cost of embracing a seemingly "realist" value such as animal welfare is less than many Kantians have been led to think, a modest philosophical price to pay for bringing animals within the ambit of direct moral concern.

The "logocentrism" that led Kant to deny direct duties to animals should therefore be rejected, but animal welfare, I contend, can be grafted onto a recognizably Kantian morality, even a constructivist one. Granted, I have not given a positive argument for why animal welfare, a nonderivative and final value, is a source of direct duties. I have shown that animal welfare is good for animals in approximately the same way that happiness is good for human rational agents, by contributing to their welfare, though its moral value is not contingent on the presence of the good rational will. I confess that I do not know how to defend these direct duties except to claim that moral agents have obligations to respond appropriately to what is good, even when a particular good stands in no normative relation to those agents and their practical rationality. To the question, "I see that animal welfare is good, but what reason have I to care about that?" I can only suggest that the question is intelligible only to those Kantians who hold fast to a theoretical dogma that gains them little and whose rejection is less costly than it appears. As we shall see in the next section, the practical costs of rejecting this dogma are also less than they might first seem.

\footnotetext{
19 “A right of self-termination?", Ethics 109 (1999): 606-28.

${ }^{20}$ Korsgaard, Sources of Normativity, 46.
} 


\section{AN IMPERFECT GONSEQUENTIALIST DUTY}

The considerations adduced so far are sufficient, to my mind, to show that animal welfare can serve as an end in itself and hence as the basis for a direct duty. Reaching this conclusion means rejecting two dogmas of Kantian ethics. The first is that all goods can be classified in terms of Kant's distinction between unconditioned and conditioned goods. The second is that being unconditionally good is necessary and sufficient to be an end in itself and therefore to be the object of direct duties. More generally, I have argued that Kant's Formula of the End in Itself should be expanded to claim that humanity as well as the animal capacity to flourish or to suffer should be treated as an end in itself.

Let us now fill in the content of this direct Kantian duty to promote animal welfare. Acknowledging such a duty requires us to reject the Kantian claim that any an end in itself possesses the pricelessness or incomparable value Kant designated as "dignity." But rejecting that claim keeps the core of Kant's ethics (and, in particular, his account of the duties we owe ourselves and to other rational agents) intact.

I have argued that animal welfare, being a nonderivative and final good, is the basis for a direct Kantian duty. This duty has two facets: while we cannot secure animals' rational consent to our actions, it is nevertheless possible not to accord their welfare sufficient moral consideration when pursuing our ends. Hence, animal welfare limits how we may use animals as means - we may not cause them to suffer merely for our entertainment, to undergo painful experimental procedures to enhance human knowledge or happiness where painless alternatives exist, etc. Furthermore, while my view would not require vegetarianism per se, it would certainly frown upon raising food animals in miserable conditions or in ways that inhibit their capacity to function as members of their species, and it would reject killing food animals in painful ways. Animal welfare is thus an end in itself in a negative sense, since animals' capacity to suffer or thrive places moral limits on the ways in which we may pursue our ends. Second, this duty entails that, irrespective of whether animal welfare is well- or ill-served by how we pursue our ends, animal suffering is an end to be avoided and animal welfare or flourishing an end to be pursued. Animal welfare is thus an end in itself in a positive sense, as an outcome to be pursued in the course of our everyday doings. And unlike Kant's own view, these duties rest upon the regard they show for animal welfare, not the ways in which these practices brutalize our moral sensibilities or express bad moral character.

The direct duty I defend here is thus analogous to our imperfect duty of beneficence toward other human beings. In Kant's terms, this means that we 
have a duty to make animal welfare a general end or maxim, but not a duty to promote animal welfare at every opportunity or to the utmost. As duties of virtue, imperfect duties leave us with "playroom for free choice" in how we comply with them. So just as our duty of beneficence, that is, the duty to advance other humans' happiness by promoting their morally permissible ends, is an imperfect and wide duty, our imperfect duty to promote animal welfare does not entail that we are morally required, qua individual agents, to rescue every mistreated animal, etc. (MM 6:390-94). Yet imperfect duties are nevertheless direct duties. Hence, the latitude we have in fulfilling these duties does not entail that they are not owed to animals as such, any more than the imperfect character of our duty of beneficence to human beings shows that it is not a duty to those beings. Furthermore, given that those duties Kant classifies as perfect duties, such as keeping promises or refraining from deception, are duties which, when transgressed, inhibit others' capacity to pursue their rationally chosen ends, it is natural that the duties we owe animals would not be perfect duties. And, indeed, the notion that we have duties not to lie to animals or to keep our promises to them is odd. ${ }^{21}$

Yet there is also an important discontinuity between the imperfect duty to promote animal welfare and the imperfect duty to promote human happiness. In the latter case, this duty is constrained by our perfect duties to human agents. We are not, for example, to deceive, coerce, or kill human agents in order to augment happiness, whether our own or others'. The relationships between these two types of duties is part of what lends Kantian ethics its nonconsequentialist character. In fulfilling our perfect duties, we respect or honor rational agency, rather than promote it. In fulfilling our imperfect duty to advance the happiness of others, we are promoting rational agency not in the sense that we are creating more of it, but in the sense that beneficence aids others in achieving their rationally chosen ends. We are, in effect, rendering their rational autonomy more efficacious in realizing their chosen ends. Here the rational agency of others is our end in a productive or causal sense. That our perfect duties, which thus have a nonconsequentialist logic, constrain our imperfect duties, which have a teleological logic, is part of Kantianism's nonconsequentialist pedigree.

In the case of animals, however, I have denied that we owe them perfect duties the fulfillment of which constrains the fulfillment of our imperfect duty to promote their welfare. This denial has substantive implications for the logic of this duty. More specifically, the imperfect duty to promote animal welfare can have a consequentialist logic that the duty to promote human happiness could not have because perfect duties constrain the latter's pursuit. What

\footnotetext{
${ }^{21}$ Timmermann, "When the tail wags the dog," 137.
} 
makes an act the fulfillment of this duty is that the agent seeks to promote animal welfare as an end. This gives our direct duty to animals its consequentialist flavor. Yet because this is an imperfect duty, it rests on demands more akin to a satisficing, rather than a maximizing, consequentialism.

This consequentialist logic makes sense of the divergence in our intuitions concerning the treatment of animals and the treatment of human beings. It is morally permissible to euthanize animals under some circumstances, to submit them to sterilization, to intervene in ecosystems to maintain numerical balances between predator and prey species, and to capture specimens of endangered species for study designed to improve their species' future prospects. Such interventions are justified on the grounds that even though they diminish animal welfare to some degree, animal welfare may be greater on the whole or in the long run. But few would endorse subjecting human agents to such interventions. So whereas consequentialist thinking appears to have a strong role in our considered views about how we may treat animals, it has no such role in our considered views about how we may treat human beings. My revised Kantian view thus offers a plausible consequentialist approach to animal welfare that does not contradict the nonconsequentialist norms Kantians favor with respect to human morality.

Critics may allege that this consequentialist logic implies that my modified Kantian view does not actually ascribe intrinsic moral status to animals, so that the duties in question are not in fact duties to animals at all. Such critics may press a variation of a familiar objection to utiltiarianism - in its most straightforward incarnations, utilitarianism directs us to maximize overall welfare, without inherent regard for the distribution of said welfare. But then the notion that any particular duties are owed to particular individuals becomes opaque. It may sometimes be true that, say, a promise should be kept to a particular individual according to utilitarianism. But this seemingly personal duty is justified by appeal to the impersonal duty to maximize overall welfare, so the keeping of a promise to a given individual is merely incidental to a larger impersonal duty. So too, critics may allege, the satisficing consequentialist stance toward animal welfare that I have defended does not generate a duty to animals but a duty to promote animal welfare in an impersonal fashion.

In one respect, this objection is correct. The revised Kantian view I have defended claims that we are obligated to give animal welfare a certain standing in our moral deliberations. It is animal welfare, not animals as such, that has nonderivative value, I have claimed. Yet if I have succeeded in showing that animal welfare is an end in itself rather than deriving its value from its relation to rational wills, it becomes incoherent to suppose that the duties resting on 
this end are merely indirect duties to animals. After all, for every indirect duty, a duty concerning $\mathrm{X}$, there is some individual who would be wronged when duties concerning $\mathrm{X}$ go unfulfilled. But there is no other candidate besides animals themselves for the individuals who would be wronged when the duty to promote animal welfare goes unfulfilled. So if there is a direct duty to promote animal welfare, we owe its fulfillment to animals themselves.

Perhaps such critics worry that my view makes animal welfare so fungible that it makes talk of duties to animals incoherent. If the duty to promote creature A's welfare can be trumped by a duty to promote creature B's greater welfare, then in what sense do I have a duty to creature A to promote its welfare? But this seems to confuse the object of a duty with its stringency. That a duty owed to $\mathrm{S}$ can be overridden by other considerations does not show that this duty is nevertheless owed to $\mathrm{S}$. Likewise, if more welfare is promoted if we benefit creature $\mathrm{A}$ than if we benefit creature $\mathrm{B}$, it does not follow that the obligation to promote B's welfare is not a duty to B.

We arrive at the same picture - a consequentialist ethic for animals allied with a nonconsequentialist ethic for human beings - when we consider what my revised Kantian view implies concerning whether animals have dignity. The notion of dignity performs two roles in Kant's ethics. First, "dignity" designates that property distinctive to rational wills that differentiates them from all other goods. Our capacity for morality, Kant argues, is what makes our humanity "that alone which has dignity" (G 4:435). As beings capable of acting autonomously in accordance with practical laws, we therefore have a worth determined by nothing but this lawgiving capacity and so have "dignity ... an unconditional, incomparable worth" (G 4:436; see also G 4:434, G 4:439-40; MM 6:436). Second, "dignity" designates a distinctive measure of value. Everything, Kant claims, has either dignity or price. "What has a price can be replaced by something else as its equivalent; what on the other hand is raised above all price and therefore admits of no equivalent has a dignity" (G 4:434; see also MM 6:434-45). That which has dignity has an "inner worth" that is not "relative" and so cannot be exchanged for other goods of its own, or any other, kind (G 4:435). Persons are thus to be "exalted above any price" (MM 6:435). Thus, dignity appears to be both a kind of value and a measure of value. Somewhat confusingly, Kant appeared to hold that rational wills have a certain unsurpassable value (dignity instead of price) due to the kind of value they have (dignity). But as we have seen, the sort of distinctive value that rational wills have (or at least can have insofar as rational wills may become good wills) is that they are unconditioned goods. Thus, we may surmise that being an unconditioned good, since it is unique to rational wills, and having dignity, since it too is unique to rational wills, are either coextensive or differ only conceptually. 
Animal welfare, I have argued, is a nonderivative and final good, but not an unconditioned one. Hence, animal welfare has a price, rather than dignity. But this is a welcome result, for rather than offending against a reasonable or compassionate animal ethic, this claim affirms such an ethic. With respect to our duties governing human interaction, dignity is what blocks tradeoffs between rational autonomy and happiness. However, because animal welfare is an end in itself but animals lack dignity, destroying or harming individual animals for the sake of their own welfare, along with the aforementioned tradeoffs of the welfare of some animals for the greater welfare of others', are morally permissible. Such actions, if directed at human agents, would clearly be impermissible (or impermissible absent rational consent), since "maiming, damaging, or killing" a human being treats her as a mere means ( $\mathrm{G} 4: 460)$. That they are permissible when directed at animals is an indication that because animal welfare does not have dignity, it is not irreplaceable or "beyond price," and therefore, consequentialist reasoning is justified with respect to our treatment of animals where it would be unjustified, at least for Kantians, with respect to our treatment of human agents.

At the same time, that human agents have dignity but animals do not allows my revised Kantian view to evade the familiar charge of speciesism. Suppose that, on a hike through the woods, you come upon a child being attacked by a hungry bear. The circumstances are such that only the use of deadly force will dissuade the bear from her attack on the child. Fortunately, you brought your rifle on the hike. Are you prima facie morally permitted - or perhaps even required - to shoot the bear? Even those philosophical advocates of duties to animals who strongly insist that views like Kant's are objectionably speciesist ought to concede this course of action is at least morally permissible. But such a concession requires an explanation making reference to a morally salient difference between a bear and a human child. My revised Kantian view provides it: The bear's welfare is an end in itself, and so too is the rational will of the child. But the child's rational will is a source of unconditioned value and hence has dignity, whereas the bear's welfare has price. Thus, in an intractable conflict between the bear and the human child our obligations to the latter supersede our obligations to the former. My revised Kantian view thus explains our moral partiality for humans over other species despite the welfare of animals functioning as an end in itself. It is therefore speciesist, but not groundlessly or arbitrarily so.

My revised Kantian view thus results in an attractive dualistic conception of moral status. Kant's own view of our duties with regard to animals is unsatisfying due to its monistic conception of moral status wherein all and only rational agents have moral status. But philosophical advocates of direct duties 
to animals - many of whom adamantly reject Kant's conception of moral status - tend to end up appealing to monistic conceptions of their own (that all and only beings who can experience pleasure and pain have moral status, for example). Their monistic conceptions of moral status impartially accord moral status to animals, but thereby fail to explain what seems to be a morally justified partiality toward humans. Monism thus leaves Kant unable to capture what is distinctly morally significant about animals, but it leaves some of his critics unable to capture what is distinctly morally significant about human beings. My dualistic conception of moral status avoids both these errors. Of course, a full defense of prioritizing respect for rational agency over the promotion of animal welfare would require a thorough defense of the Kantian axiological system, that is, it would require showing that rational agency has this value and why. Obviously I cannot provide such a defense here. I merely note that we are not forced to choose between Kant's monism and other monisms concerning moral status. It is not incoherent to suppose that moral status comes in multiple kinds, and if so, that such kinds might instantiate nonderivative values with different logics - some may have dignity, others price, some unconditioned, etc. Given this possibility, it is not implausible for partiality toward certain of these values to be justified despite there being other nonderivative values.

It may be asked just how far this proposed partiality extends. For example, how might my revised Kantian view adjudicate conflicts between human biological or economic needs and animal welfare (e.g., deforestation or pollution that harms or kills animals)? I make no pretense of answering this question with any specificity. But while an ability to solve moral conflict is a reason to adopt a particular theoretical stance, an ability to explain why some moral conflicts are daunting, even intractable, is a reason to adopt a particular theoretical stance as well. And one virtue of my revised Kantian view is that it helps us appreciate why such conflicts raise the hardest questions for any animal ethic. For such conflicts juxtapose values or goods which, on my view, are incommensurable because they occupy different axiological spaces. Animal welfare is a good that is neither rooted in, nor augmented or diminished by, rational volition. Human needs are conditionally good with respect to the unconditioned good of rational volition. And rational volition is the basis for our having incomparable dignity as human agents. Such conflicts thus involve friction between two value schemes with contrasting logics and natures. While utilitarian approaches to animal ethics promise to resolve such friction by making welfare a common measure, we might equally reject such approaches on the grounds that they attempt to harmonize values which, by their nature, resist such harmonization. 


\section{GONCLUSION}

To review: Animal welfare is neither unconditionally good nor a source of dignity. However, animal welfare is an end in itself because it is a nonderivative and final good. Thus, there exists a direct duty to promote animal welfare. This duty is imperfect and operates according to a consequentialist logic. In order to argue for this revised Kantian view, I have had to reject three common Kantian dogmas: that all goods are either unconditionally good or conditionally good in relation to the unconditionally good; that only unconditioned goods can be ends in themselves and thus ground direct duties; and that any end in itself also has dignity or pricelessness. In recognizing two kinds of ends in themselves and two sources of moral obligation, my revised Kantian view represents a somewhat radical departure from Kantian orthodoxy. But rejecting these three dogmas does not, I contend, threaten the core of Kantian morality regarding interactions among rational agents. Indeed, many central Kantian ethical doctrines are left undisturbed, including: the status of the Categorical Imperative as morality's supreme principle, the system of duties developed from the Categorical Imperative, the rationalistic requirement that moral demands are rational demands, the special status of the rational will as both the sole unconditioned good and the only good with dignity, etc.

My argument is not the first Kantian effort to try to ground direct duties to animals. But suffice to say that other such efforts have been not only frustratingly oblique but represent at best only "technical" victories unlikely to persuade Kantianism's opponents. ${ }^{22}$ My argument grounds this duty on animal welfare itself, not on the problematic claim that we should respect animals because they possess "fragments" or conditions of rational agency. ${ }^{23}$ At a more gut level, my revised Kantian view rejects the solipsistic or anthropocentric tendency to use those differences that distinguish human agents from animals as a basis for denying animals any moral standing at all. ${ }^{24}$

\footnotetext{
${ }^{22}$ O’Hagan, "Animals, Agency, and Obligation in Kantian Ethics," 531-2.

${ }^{23}$ Allen Wood, "Kant on Duties Regarding Nonrational Nature I." Both Skidmore, "Duties to Animals: The Failure of Kant's Moral Theory," 544-7 and O'Hagan, "Animals, Agency, and Obligation in Kantian Ethics," 545-8 reject Wood's position on the grounds that respecting rational agency does not seem to require respecting the conditions or components of rational agency.

${ }^{24}$ I gratefully acknowledge the valuable feedback on this article provided by the reviewers of this journal, as well as by Steve Munzer, Sharon Lloyd, Herbert Morris, Zac Coglan, David Kaspar, John Davis, Jason Raibley, and Matthew Altman, and from audiences at California State University, Long Beach, and the University of Nevada-Reno.
} 